Water Quality and Monitoring Track

Journal of South Carolina Water Resources

Volume 2, Issue 1, Pages 86-92, 2015

\title{
Groundwater Recharge Rates in Isolated and Riverine Wetlands: Influencing Factors
}

\author{
Chenille Williams ${ }^{1}$ and Dan Tufford ${ }^{1}$
}

AUTHORS: ' ${ }^{1}$ University of South Carolina, Columbia, SC 29208, USA.

\begin{abstract}
Isolated wetlands and riverine wetlands have been shown to have similar groundwater hydrology despite their difference in topography and surface water hydrology. The current study aimed to address the impact of topography and surface water hydrology on groundwater hydrologic behavior by comparing the groundwater recharge rates of several isolated and riverine wetlands in the Coastal Plain of South Carolina. Study sites contained an isolated wetland, a riverine wetland, and an upland that bisected the two wetland types. Shallow water tables and sandy soils, allowed a rapid response to precipitation to be clearly visible. Soil characteristics, water table fluctuations, and precipitation data from January 2012-September 2012 were evaluated and from that data mean recharge rates were calculated using an adapted version of the water table fluctuation method. During the study period, it was observed that the frequency of precipitation (storm events) and saturated zone soil type were more impactful on water table movement than topography, surface soil type, and surface water hydrology. One significant finding of this research is that the isolated wetlands in this study did, in fact, recharge groundwater, which implies that their presence increases the opportunity for groundwater replenishment.
\end{abstract}

\section{INTRODUCTION}

One of the many functions of wetlands is the ability to capture stormwater runoff and recharge groundwater (Richardson, 1994; van der Kamp and Hayashi, 1998). Studies have suggested that riverine wetlands and geographically isolated wetlands may share that hydrologic capability (SEIWA, 2011), but further research into isolated wetland groundwater hydrology is needed.

With groundwater being a drinking water source for rural residents and an irrigation water supply for agriculture activity, groundwater hydrological processes are considered when assessing the water budget of an ecosystem and accounting for groundwater supply replenishment. Because groundwater is such a valuable resource, it is important to understand factors that may affect recharge processes. The objective of this study was to explore the groundwater hydrology of isolated and riverine wetland systems, compare their recharge rates, and assess factors that influence their recharge capabilities.

Over time, it has been recognized that riverine wetlands provide recharge opportunities; however little research specifically on recharge in isolated wetlands has been conducted in the Southeastern United States. Findings of this nature often become the basis of conservation laws, for which there may be a need of in many states. When making decisions, land managers and owners may not always have an interest in groundwater resources. Thus, it is up to state regulation to provide directives on groundwater protection. Knowing what factors affect groundwater supply (and potentially surface water quality) can be advantageous when making land disturbance permitting decisions.

\section{BACKGROUND}

Isolated wetlands are located throughout the United States, with characteristics that vary with geographic location, climate, and geomorphology. These microhabitats are called depressional wetlands, as they have a slightly depressed topography surrounded by an upland area. Most notably, isolated wetlands have no immediate surface water connection - a direct contrast to riverine wetlands, which often serve as riparian zones. One component of the water budget of both wetland systems is groundwater recharge - the addition of water to a subsurface aquifer. This type of input is valuable because it functions as a water source during low river flows and low precipitation, and its abundance affects human, animal, and plant populations (Richardson, 1994; Achayra and Barbier, 2000). Groundwater recharge rates have implications for shallow groundwater quality and those rates can be impacted by many factors including climate, topography, soil saturation, and soil texture.

While there is an overall variation in the topography of isolated and riverine wetlands, the hydropatterns of both systems create the opportunity for the development of hydric soils. Soil profiles vary regionally and the presence of a hydric soil has to be made based on the evaluation of the soil in each specific location. Pore size within the texture of a hydric soil determines the speed at which the pore pressure equilibrates (Williams, 1978). As a result, soil textures with 
large pores allow water to move more readily than soil textures with small pores. Little research has been conducted to directly assess the similarity between the soil profiles of isolated and riverine wetlands within close proximity of one another - a factor that may influence the similarities between their recharge capabilities.

Until recently, most of the isolated wetland research has focused on prairie potholes in the Midwestern United States. Although that research provides insight on general isolated wetland behavior, the same behavior cannot be expected of wetlands in the Southeastern US, such as Carolina Bays and pocosins, due to the different climate, geomorphology, and wetland type. Since 2010, several studies have focused specifically on the hydrology of isolated wetlands in the southeastern region of the United States. Callahan et. al. studied the groundwater recharge rates of several isolated wetlands in South Carolina (2012), while the Southeastern Isolated Wetland Assessment (SEIWA, 2011) and the Hydrologic Connectivity, Water Quality Function, and Biocriteria of Coastal Plain Geographically Isolated Wetlands study (IWC, 2013) both assessed the surface water quality, groundwater quality, and groundwater nexus between isolated and riverine wetland systems. Additional research will increase the current body of knowledge about isolated wetland systems and how their functions compare to riverine wetland systems.

\section{METHODS}

In this study, recharge was defined as a change in water table height as caused by water percolating through the vadose zone to the zone of saturation (Lerner et. al., 1990; Devries and Simmers, 2002). The sites used for this study were within wildlife management areas in Marion County (Site MA and Site MF) and Horry County - both located in the Coastal Plain of South Carolina. Each of the three study sites contained two wetlands - one isolated and one riverine - and an upland that bisected the two wetlands types (Figure 1).

\section{Groundwater Monitoring}

At each site, a transect of groundwater monitoring wells was installed in the surficial aquifer from the isolated wetland to the riverine wetland (Figure 1). Each well location was identified with a "sub-site" based on its placement within the site. Isolated wetland (IW) indicated the edge of isolated wetland. Upland identified the upland area between the two wetlands. Connected wetland (CW) identified a location at the edge of the riverine wetland. Riverine wetland (RW) referred to a location in the riverine wetland that is closer to the surface water. Across all three sites, a total of 13 wells were installed and outfitted with pressure transducers whose accompanying software translated water and air pressure measurements to changes in water table depth. Water level

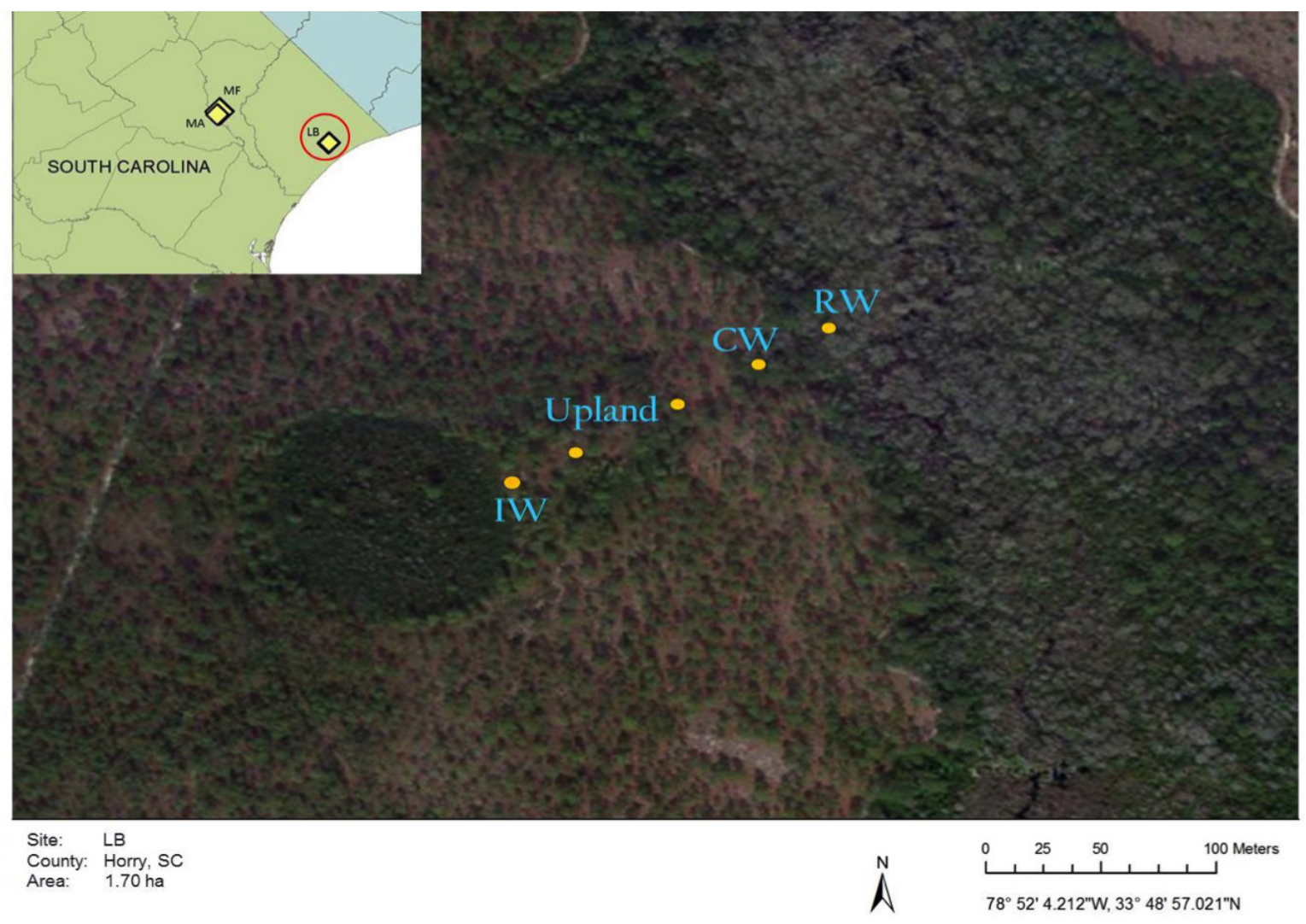

Figure 1. Layout at LB site in Horry County, SC. IW indicates edge of isolated wetland, Upland indicates upland area, CW indicates the edge of the riverine wetland and RW indicates a location in the riverine wetland closer to the surface water. 
loggers were programmed to record hourly temperature and depth to water from the top of the well's casing. Logger data was downloaded every two months from January 2012 - September 2012. During each download event, a discrete water level measurement was taken using an electronic water level meter. This data was used to establish an initial depth to water measurement from a designated measuring point at the top of the well casing (from which the logger was calibrated), and to correct for electronic drift of the loggers. Differential level surveys were also conducted to determine the elevation above sea level at the top of each well casing. Continuous monitoring data for each site was then compiled into hydrographs to analyze the water table's behavior.

\section{Soil Profiles and Precipitation}

During the time of well construction, soil profiles were created to note changes in texture and/or color with depth. The observed profiles were compared to soil data from the Natural Resources Conservation Service for continuity. From the recorded data, stratigraphy maps for each site were created in order to display the underlying soil layers along the transect. Tipping bucket-style rain gauges that measured hourly air temperature and amount of precipitation were installed at each site in an open area to prevent overhead interception. Because of the sparsely interrupted overhead vegetation at the MF site, one rain gauge was used for both Marion County sites. Data from the rain gauges were also downloaded every two months during the same time the logger data was downloaded and the discrete water level measurements were taken.

\section{Recharge Calculation}

Recharge rates at each sub-site were calculated using the water table fluctuation (WTF) method, which is best used for unconfined aquifers (Healy and Cook, 2002) with shallow water tables that have a rapid response to precipitation (Moon et. al., 2004). The WTF method uses a water table budget to assume that a rise in the water table, as measured by an increase of water level height in a surficial groundwater well, is caused by recharge (Healy and Cook, 2002; Crosbie et. al., 2005). In an equation adapted by Callahan et. al. (2012), recharge is measured as:

$$
R=\left[S_{y}\left(h_{a}-h_{m}\right)\right] / \Delta t
$$

where $\mathrm{R}$ is the rate of recharge [ $\mathrm{cm} /$ day] from the maximum water table depth $\left(\mathrm{h}_{\mathrm{a}}\right)[\mathrm{cm}]$ to the minimum water table depth $\left(\mathrm{h}_{\mathrm{m}}\right)[\mathrm{cm}], \mathrm{S}_{\mathrm{y}}$ [dimensionless] is the specific yield, and $\Delta \mathrm{t}$ is the duration of the recharge event [days] (Scanlon et.al., 2002; Healy and Cook, 2002; Callahan et. al., 2012).

Equation 2 was used to account for natural groundwater recession rate in the absence of precipitation in order to determine $h_{a}$. The equation, which was originally used by
Zhang and Schilling (2006) and adapted by Callahan et. al. (2012), is written as:

$$
h_{a}=h_{i}+h_{0}\left[1-e^{-a t}\right]
$$

where $h_{a}[\mathrm{~cm}]$ is the projected water table depth at the end of the recession period, hi $[\mathrm{cm}]$ is the water table depth at the beginning of the recession period, $h_{0}[\mathrm{~m}]$ is the observed maximum water table depth at the end of the recession period, $\alpha[\mathrm{d}-1]$ is the recession coefficient, and $\mathrm{t}[\mathrm{d}]$ is time.

Using a sub-set of the water level data, $\mathrm{S}_{\mathrm{y}}$ values were calculated using a formula established by Williams (1978) and adapted by Callahan et. al. (2012). In the formula:

$$
S_{y}=P / \Delta h
$$

$\mathrm{S}_{\mathrm{y}}$ is specific yield [dimensionless], $\mathrm{P}$ [cm] is precipitation, and $\Delta \mathrm{h}[\mathrm{cm}]$ is the change in hydraulic head prior to the water table rise.

Using sub-sets of the data collected $\mathrm{S}_{\mathrm{y}}$ and $\mathrm{h}_{\mathrm{a}}$ were calculated. Those results were then used in Equation 1 to calculate the rate of recharge in response to designated rain events. Qualifying rain events had to fall within a certain range of duration, amount of precipitation, and time frame in order to be used. These restrictions were created to ensure a rise and fall could be attributed to a specific rain event.

\section{RESULTS}

\section{Soil Profiles}

All of the study sites were located in the Coastal Plain of South Carolina and underlain by sandy soils. Both the IW (Well 1) and RW (Well FL) at the LB site in Horry County contained silty loam topsoil (Figure 2). As shown in Figure 3 , the topsoil at the MA site in Marion County contained a silty loam and loam at the CW (Well 3) and IW (Well 1) subsites, respectively. The topsoil at the MF, shown in Figure 4, site contained a loam and clay loam at the RW (Well 4) and IW (Well 1) sub-sites, respectively. The upland areas at eachof the study sites contained a soil texture with a higher percentage of sand than that of either of the wetland subsites. Despite their different locations, and varying topsoil textures between the upland and wetlands sub-sites, each site was underlain by a sandy soil approximately $2.0 \mathrm{~m}$ in depth wherein the water table was located.

\section{Analysis of Recharge Rates}

In comparing the rates across all the study sites, the fastest rates were observed at the RW sub-sites in both Marion County sites (MA $=5.73 \mathrm{~cm} /$ day, $\mathrm{MF}=5.90 \mathrm{~cm} /$ day), and the $\mathrm{CW}$ sub-site at the Horry County site $(\mathrm{LB}=5.22 \mathrm{~cm} /$ day), as shown in Table 1. When the rates displayed in Table 1 are averaged, the riverine wetlands have an overall faster rate at $4.73 \mathrm{~cm} /$ day than the isolated wetlands at $3.29 \mathrm{~cm} /$ day. Because the calculated mean recharge rate does not indicate 


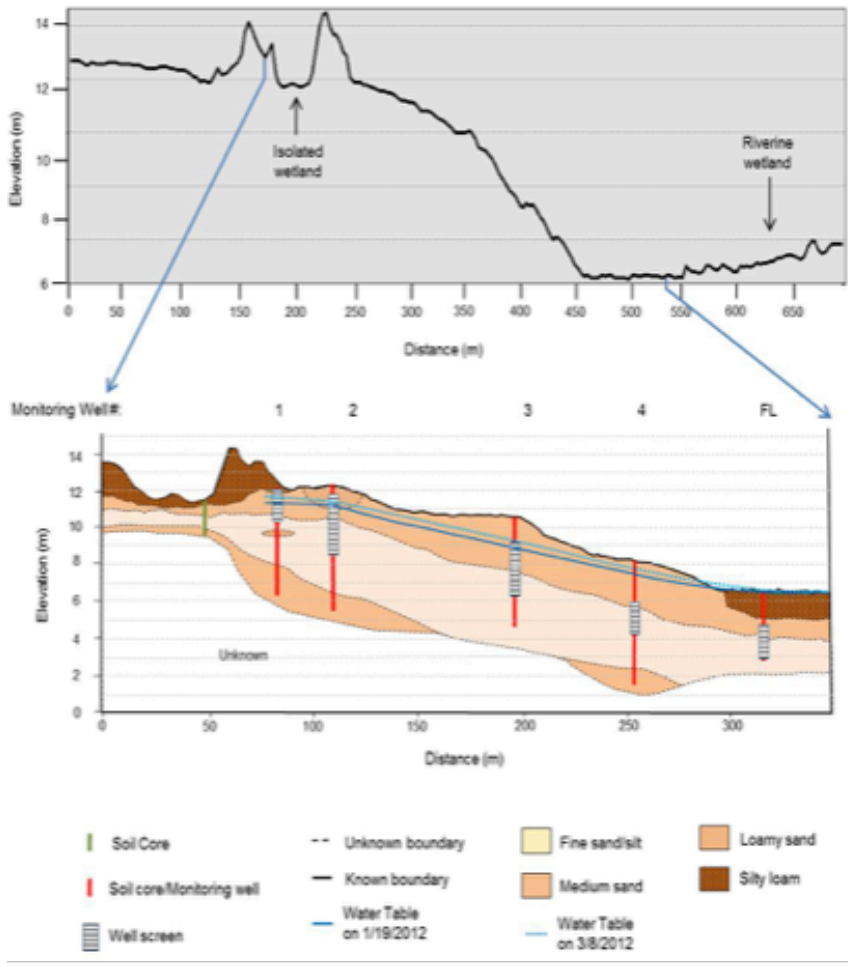

Figure 2. Stratigraphic map of the soil profile at the LB site. Vertical exaggeration: $24.4 \mathrm{x}$ (upper image) and $8.3 \mathrm{x}$ (lower image)

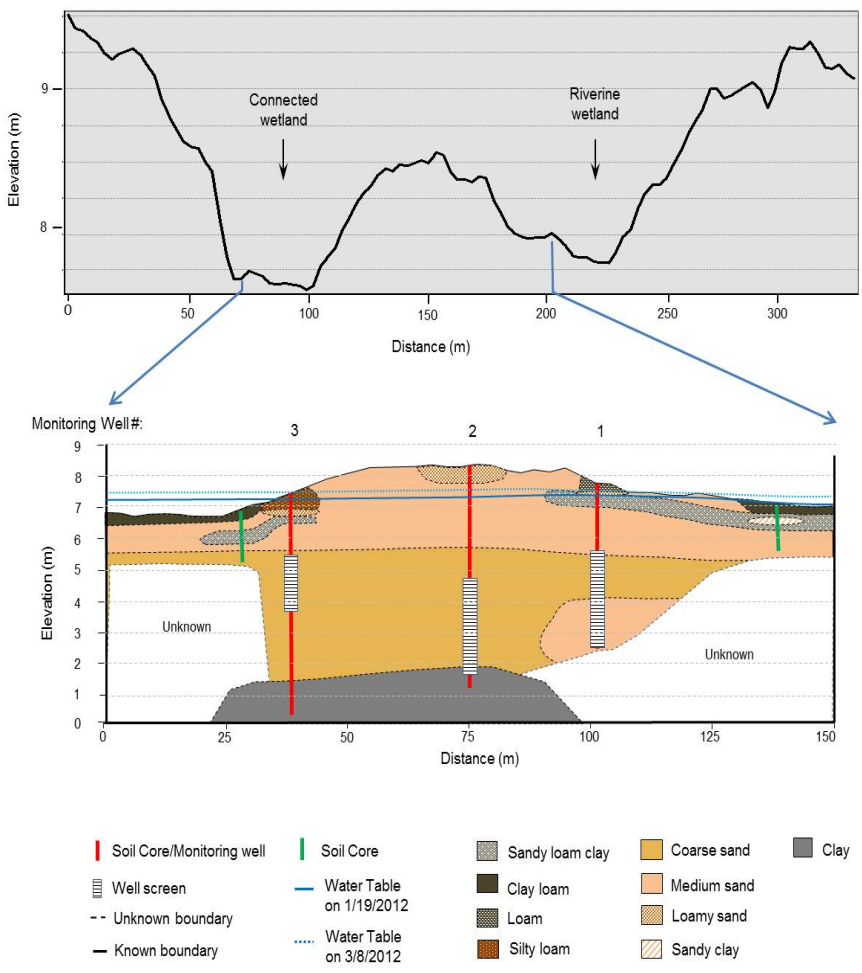

Figure 3. Stratigraphic map of the soil profile at the MA site. Vertical exaggeration: 49.6x (upper image) and 5.3x (lower image).

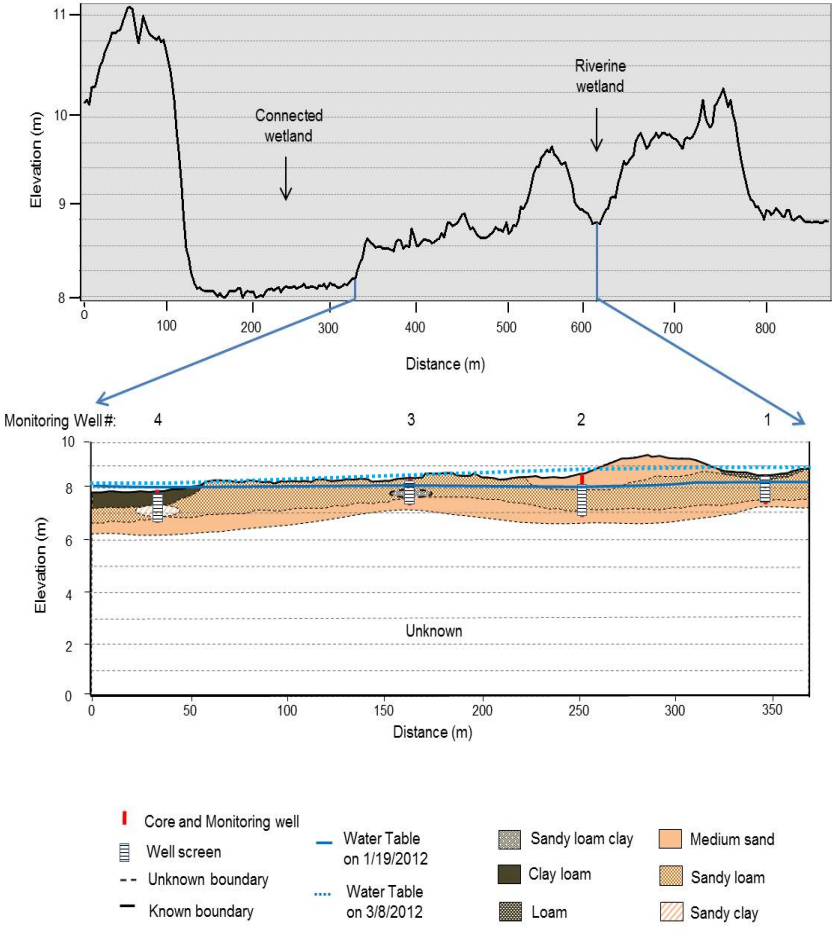

Figure 4. Stratigraphic map of the soil profile at the MF site. Vertical exaggeration: 89.3x (upper image) and 12.7x (lower image)

Table 1. Mean recharge rates \pm standard deviation ( $\mathrm{cm} /$ day) per subsite type

\begin{tabular}{|l|c|c|c|c|}
\hline Site & IW & Upland & CW & RW \\
\hline LB & $3.32 \pm 4.05$ & $3.11 \pm 3.11$ & $5.22 \pm 3.52$ & $2.56 \pm 1.87$ \\
\hline MA & $2.73 \pm 3.23$ & $1.55 \pm 1.43$ & $1.64 \pm 2.09$ & $5.73 \pm 4.70$ \\
\hline MF & $3.81 \pm 2.34$ & $2.97 \pm 2.88$ & - & $5.90 \pm 6.18$ \\
\hline All & $3.29 \pm 0.54$ & $2.54 \pm 0.86$ & $3.43 \pm 2.53$ & $4.73 \pm 1.88$ \\
\hline \multicolumn{5}{|c|}{ * not all sites have the connected wetland (CW) sub-site }
\end{tabular}

a significant different in rates between sub-sites (or sites), a MANOVA statistical test was run using land type (i.e. IW, CW, upland, RW) as a factor to determine if different wetland sub-sites produced different recharge rates. Based on the Wilks' Lambda p-values $(\alpha=0.10)$, there was no significant difference in the mean recharge rate between the different sub-sites within each site $(\mathrm{LB}=0.162, \mathrm{MA}=0.157$, $\mathrm{MF}=0.349$ ). In other words, for each of the three sites, there was not a significant difference between the mean recharge rates observed at the IW, upland, $\mathrm{CW}$, or RW within that site, nor was there a difference between the rates of all the subsites between the sites (e.g. the rate from collective IW data from all the sites was no different from the same data set from the RW collective data). 


\section{Analysis of Storm Events}

A qualitative observation made during the hydrograph analysis was a difference in water table recession as the occurrence of storm events increased during the study period. Although the South Carolina State Climatology Office had declared a drought status during the early portion of this research, the study period was too short to infer that the observed changes were caused by climate variability. A distinction between the "wet" and "dry" periods was made based on the precipitation frequency, or frequency of storm events. For the Marion County sites, the dry period was from January - April 2012 and the wet period from May - June 2012. For the Horry County site, the dry period was from January - March 2012 and the wet period from April - September 2012. The dry and wet periods were also determined based on the variation in water table responses to change in precipitation frequency as observed from the hydrographs (Figure 5, Figure 6, Figure 7).

The change in precipitation appeared to be significant enough to impact the water table's natural recession rate; as a result, a second MANOVA statistical test was run using precipitation frequency as a factor with the recharge events being categorized as occurring in either the dry or wet period. The Wilks' Lambda p-values $(\alpha=0.10)$ for that analysis indicated that changes in precipitation frequency elicited a statistically significant impact on mean recharge rates at the LB site $(\mathrm{p}=0.048)$, MA site $(\mathrm{p}=0.042)$, and MF site $(\mathrm{p}=0.103)$. Although the type of wetland did not impact the rates, the amount of precipitation within a given period did.

\section{DISCUSSION}

The results of this study concluded that there was not a statistically significant difference in the mean recharge rates of the isolated and riverine wetlands used in this study. However, as the occurrence of storm events increased throughout the duration of the study period, there was a change in recharge rates observed at each of the wetland types. This change was noted as causing a statistically significant difference. Ultimately, weather patterns impacted groundwater recharge rates more than the type of wetland at which the recharge occurred.

The responses to weather patterns were based on the wet and dry periods established during the study period, and not necessarily not climate. Although the South Carolina State Climatology Office had declared a drought status during the early portion of this research, the study period was not long enough to definitively attribute any changes in weather to overall climate patterns. However, as the occurrence of storm events increased, the soil moisture and the hydraulic movement of subsurface water were impacted. Studies by Nolan et. al. (2007) and Callahan et. al. (2012) stress the relevance of considering deeper soil textures when analyzing groundwater behavior because hydrogeologic characteristics and water movement in the saturated zone contribute to the recharge rates in the unsaturated zone. The saturated

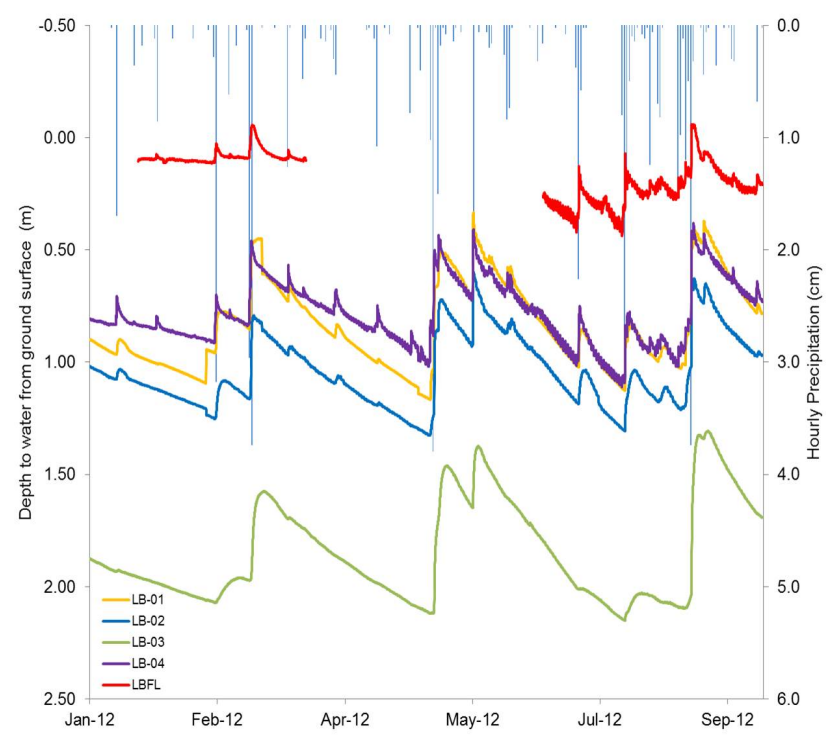

Figure 5. Hydrograph of water table fluctuations and hourly precipitation at the LB site (Horry Co., SC) from January 2012 to September 2012.

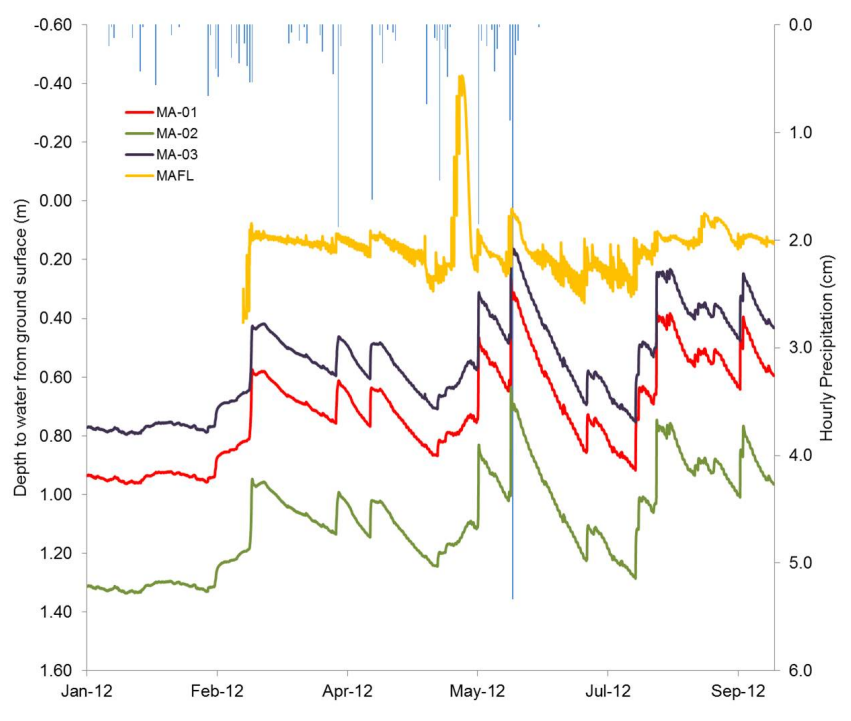

Figure 6. Hydrograph of water table fluctuations and hourly precipitation at the MA site (Marion Co., SC) from January 2012 to September 2012.

zone at each of the study sites contained a sandy soil texture throughout each well transect. That persistent soil texture presumably drove the similar hydraulic movement of groundwater at each well location (in either an isolated wetland, upland, or riverine wetland area) and resulted in the similar recharge rates despite variation in wetland type and surface soil texture. There was a potential difference in infiltration and percolation rates due to the variation in surface soil textures, but the subsurface soil texture was more of a driving factor for groundwater behavior.

While an impact on rates was not observed for the different wetland types, an impact was noted for an increase 


\section{Groundwater Recharge Rates in Isolated and Riverine Wetlands}

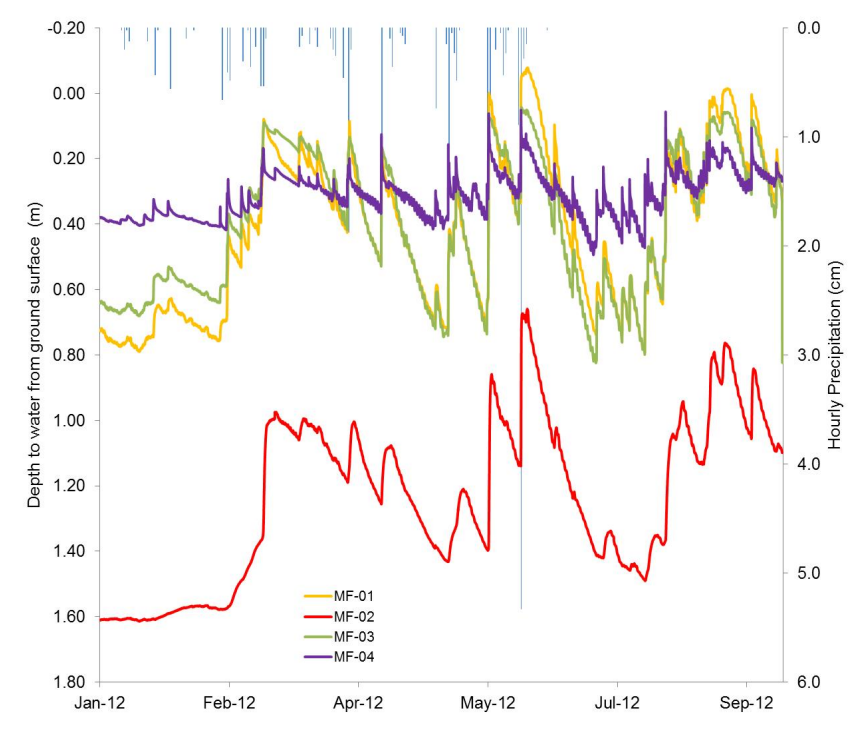

Figure 7. Hydrograph of water table fluctuations and hourly precipitation at the MF site (Marion Co., SC) from January 2012 to September 2012.

in the frequency of rain events. The difference in recharge rates between the dry and wet periods may be a result of soil moisture content and the water table's ability to fluctuate. As the occurrence of storm events increased, the amount of available soil moisture also increased. In turn, the soils were more likely to be saturated throughout the soil profile, which would impact the water table's ability to fluctuate upon receiving percolating water. Less precipitation means less available water capacity, decreased soil moisture, and freedom for the water table to fluctuate as a result of the empty pore spaces. Additionally, each of the three study sites were underlain by sandy soils, through which water flows easily and resulting in a more dramatic change in water table movement. Soil type, particle size, pore size, and soil moisture appear to dictate groundwater movement. Those four variables are affected by the amount of precipitation in a given amount of time and potentially the climatic conditions.

One of the objectives of this study was to compare the recharge rates of isolated and riverine wetlands. While the wetland types in this study did not have different recharge rates, the isolated wetlands did, in fact, recharge groundwater. The influence of isolated wetlands on the groundwater of an ecosystem is not to be overlooked, nor is the suggestion that isolated wetlands recharge groundwater to same degree as riverine wetlands. As locations of recharge, the presence of isolated wetlands increases the capability for an area to replenish groundwater resources. One could even argue that because infiltrating water collects in the depression and surrounding groundwater follows the downward slope of the depression and remains in the depression, as opposed to discharging into a flowing surface water body, isolated wetlands recharge more groundwater than uplands or riverine wetlands. Decreasing the aforementioned opportunities to replenish groundwater should be considered by regulatory agencies when making permit decisions. It would be beneficial to further pursue this line of research to increase the knowledge about additional similarities or differences between wetland systems in the South Carolina Coastal Plain. It would also be valuable to expand the research to comparing different wetland systems in other regions of the Carolinas, such as the Piedmont or the Blue Ridge.

\section{ACKNOWLEDGEMENTS}

This work was supported by University of South Carolina, U.S. EPA Office of Research and Development, National Health and Environmental Effects Laboratory, and conducted in conjunction with the Hydrologic Connectivity, Water Quality Function, and Biocriteria of Coastal Plain Geographically Isolated Wetlands. Scott Harden of South Carolina Department of Natural Resources, Wilma Simms of University of South Carolina, Alicia Wilson of University of South Carolina, Oscar Flite of Phinizy Center for Water Sciences, and Ivetta Abramyan of South Carolina State Climatology Office provided invaluable assistance and advice with data analysis. The authors also thank Warren Hankinson for assistance with field data collection, and the anonymous reviewers for their comments to improve this article.

\section{LITERATURE CITED}

Acharya, G., and E. B. Barbier, 2002. Valuing groundwater recharge through agricultural production in the HadejiaNguru wetlands in northern Nigeria. Agricultural Economics 22: 247-259.

Callahan, T. J., V. M. Vulava, M. C. Passarello, and C. G. Garrett, 2012. Estimating groundwater recharge in lowland watersheds. Hydrological Processes 26: 2845-2855.

Crosbie, R. S., P. Binning, and J. D. Kalma, 2005. A time series approach to inferring groundwater recharge using the water table fluctuation method. Water Resources Research. 41.

DeVries, J. J., and I. Simmers, 2002. Groundwater recharge: and overview of processes and challenges. Hydrogeology Journal 10:5-17.

Dorney, J. R., D. Tufford, V. Baker, F. Obusek, B. Muñoz, R. Truesdale, K. Matthews, and V. Lesser, 2012. Isolated wetlands in the Southeastern United States: A comparison of state regulatory programs and implications of recent research. National Wetlands Newsletter 34 (May-June):21-25.

Healy, R. W., and P. G. Cook, 2002. Using groundwater levels to estimate recharge. Hydrogeology Journal 10: 91-109.

Lerner, D. N., A. S. Issar, and I. Simmers, 1990.

Groundwater recharge; a guide to understanding and estimating natural recharge. International Contributions to Hydrogeology, vol. 8. Heise, Hannover, FRG., 345 pp. 
Moon, S., N. C. Woo, and K. S. Lee, 2004. Statistical analysis of hydrographs and water-table fluctuation to estimate groundwater recharge. Journal of Hydrology 292: 198-209.

Nolan, B. T., R. W. Healy, P. E. Taber, K. Perkins, K. J. Hitt, and D. M. Wolock, 2007. Factors influencing ground-water recharge in the eastern United States. Journal of Hydrology 332: 187-205.

North Carolina Division of Water Quality and University of South Carolina, 2013. Hydrologic Connectivity, Water Quality Function, and Biocriteria of Coastal Plain Geographically Isolated Wetlands (IWC). Final Report for U.S. EPA Office of Research and Development, National Health and Environmental Effects Laboratory. EPA Cooperative Agreement No. CD 95415809.

Preston H., 2012. South Carolina Supreme Court Issues Landmark Isolated Wetlands Opinion. National Wetlands Newsletter 34: 5-6.

Richardson, C. J., 1994. Ecological functions and human values in wetlands: a framework for assessing forestry impacts. Wetlands 14: 1-9.

RTI International, North Carolina Department of Environment and Natural Resources, South Carolina Department of Health and Environmental Control, and University of South Carolina, 2011. Assessing geographically isolated wetlands in North and South Carolina: the southeast isolated wetlands assessment (SEIWA). Final Report for U.S. EPA Office of Research and Development, National Health and Environmental Effects Laboratory. EPA Cooperative Agreement No. COA RM-83340001.

Scanlon B. R., R. W. Healy, and P. G. Cook, 2002. Choosing appropriate techniques for quantifying groundwater recharge. Hydrogeology Journal 10: 18-39.

Van der Kamp, G., and M. Hayashi, 1998. The groundwater recharge function of small wetlands in the semi-arid northern prairies. Great Plains Research 8:39-56.

Williams, T. M., 1978. Response of shallow water tables to rainfall. In Proceedings of the Soil Moisture and Site Productivity Symposium, Balmer W (ed). Myrtle Beach, South Carolina: 363-370.

Zhang, Y. K., and K. E. Schilling, 2006. Effects of land cover on water table, soil moisture, evapotranspiration, and groundwater recharge: a field observation and analysis. Journal of Hydrology 319: 328-338. 